\title{
Age, growth and mortality rates of discard species (Uranoscopus scaber, Neogobius melanostomus and Gobius niger) in the Black Sea
}

\section{Karadeniz' de ıskarta türlerin (Uranoscopus scaber, Neogobius melanostomus ve Gobius niger) yaş, büyüme ve ölüm oranları}

\author{
Nazlı Kasapoğlu \\ Central Fisheries Research Institute, Vali Adil Yazar Cad. No: 14, 61250 Trabzon, Turkey \\ nazliktu@gmail.com
}

\section{How to cite this paper:}

Kasapoğlu, N. (2016). Age, growth and mortality rates of discard species (Uranoscopus scaber, Neogobius melanostomus and Gobius niger) in the Black Sea. Ege Journal of Fisheries and Aquatic Sciences, 33(4): 397-403. doi: 10.12714/egejfas.2016.33.4.14

\begin{abstract}
Uranoscopus scaber, Neogobius melanostomus and Gobius niger are called non-commercial fish species and also caught as discarded in Turkish fisheries. Samplings were carried out by bottom trawl, gillnet, purse seine net operations in the Turkish Black Sea coasts. The results of the study showed that age of these species were 0-V ages for Uranoscopus scaber and Gobius niger, and 0-VII ages for Neogobius melanostomus for both sexes. The von Bertalanffy growth parameters, total mortality rate $(\mathrm{Z})$, natural mortality rate $(\mathrm{M})$ and fishing mortality rate $(\mathrm{F})$ were calculated for each species separately.
\end{abstract}

Keywords: Age, growth, mortality rates, Uranoscopus scaber Neogobius melanostomus, Gobius niger

Öz: Uranoscopus scaber, Neogobius melanostomus ve Gobius niger Türkiye ballıçlığında ekonomik olmayan balıklar olarak adlandırılmakta ve ıskarta edilmektedirler. Bu çalışmanın örnekleri Karadeniz kııısında kullanılan dip trolü, uzatma ağı ve gırgır ağları ile avlanmış̧ır. Bu çalışmadan elde edilen sonuçlar, Uranoscopus scaber ve Gobius niger türünün yaşlarının 0-V arasında, Neogobius melanostomus türünün ise 0 -VII yaş arasında değiştiğini göstermiştir. Von Bertalanffy büyüme parametreleri, toplam ölüm oranları, doğal ölüm oranları ve balıkçılık ölüm oranları ise her tür için ayrı ayrı hesaplanmışıır.

Anahtar kelimeler: Yaş, büyüme, ölüm oranları, Uranoscopus scaber, Neogobius melanostomus, Gobius niger

\section{INTRODUCTION}

Uranoscopidae family contains approximately 50 fish species living mainly in warm-water and temperate zones (Baron, 2009). The teleosts with an electric organ are two genera of the perciform family Uranoscopidae: Astroscopus and Uranoscopus, Linnaeus (Bennett, 1971; Moller, 1995). Electrogenic tissue is derived from sonic muscles in Uranoscopus genus (Moller, 1995). This genus produces pulse type electric organ discharges (EOD) generated mainly during feeding activity or when the fish is disturbed (Pickens and McFarland, 1964). Uranoscopus scaber (Linnaeus 1758) is a benthic species living in the littoral waters in sandy or muddy bottoms and distributed along Atlantic coast of Europe and Africa, Mediterranean and Black Seas (Hureau, 1986). It is a non-commercial fish species and is being caught by various fishing gears as discards in Turkey. Therefore, there is no fishing regulation, i.e. no minimum landing size (MLS) or restricted fishing time. Moreover, there is no landing statistics for this species. U. scaber notified as 'vulnerable' to a high risk of extinction in the wild for Turkey in the Red Data Book of the (c) Published by Ege University Faculty of Fisheries, Izmir, Turkey
Black Sea (Yankova et al., 2011). There are few research studies on this species in the Black Sea and other seas (Demirhan et al., 2007; Rizkalla and Bakhoum, 2009; Erdogan Saglam and Saglam, 2013).

The family Gobiidae is a large family and distributed in tropical, subtropical areas in shallow coastal marine waters. There are 1578 goby species living in the world. 74 goby species are reported in the Mediterranean and Black Seas, and 33 species of them are found in Turkish waters (Miller, 1986; Nelson, 1994; Froese and Pauly, 2009). Gobius niger is widely distributed in Eastern Atlantic, Mediterranean and Black Seas as well as North Africa from Cape Blanc, Mauritania north and eastwards to the Suez Canal; the eastern Atlantic coast and Baltic Sea (Miller, 1986; Fabi and Gianetti, 1985). G. niger is known as a common fish species in the Black Sea, but there is no fishing limitation/regulation (no MLS) due to non-commercial value in Turkey. However, this species has an important ecological importance as an indicator species. It plays a significant role in the food chain (Filiz and Toğulga, 2009; 
Katalay and Parlak, 2002). Although, the studies were conducted on this species caught from Aegean Sea related to its age, growth, reproduction, biological characteristics, diet, environmental effects and pollution (Katalay and Parlak, 2002; Filiz and Toğulga, 2009). There is only one research conducted about its age and growth parameters in the Black Sea (Van, 2012).

The other goby fish Neogobius melanostomus (Pallas, 1811) is an invasive species inhabiting in the Black and Caspian seas and was probably introduced through other seas (the seas of Atlantic, Europa and America) via ballast waters (Skora and Stolarski, 1993). This species is a successful colonist (high fecundity, wide tolerance of abiotic and biotic factors), having a short generation time, fast growth rates (Lodge, 1993). This species is commonly found in the Black Sea without any market value just as $G$. niger which are no management measures on this species in Turkey. There are numerous studies on all these species in Turkish and other seas in the world (Lodge, 1993; Skora and Stolarski, 1993; Macinnis and Corkum, 2000; Simonovic et al., 2001; Corkum et al., 2004; Kurt, 2005; Engin, 2008; Gümüs and Kurt, 2009; Sokolowska and Fey, 2011).

The present study aims to determine age, growth and mortality parameters of Uranoscopus scaber, Gobius niger and Neogobius melanostomus obtained from the Turkish Black Sea coastal waters. These parameters are required for the management of fish stocks and planning of the future for the sustainable fisheries in the framework of the common fisheries policy.

\section{MATERIAL AND METHODS}

This study was carried out in sampling stations in Hopa, Rize, Trabzon, Giresun, Ordu, Samsun, Sinop seasonally between 2008-2011 (Figure 1).

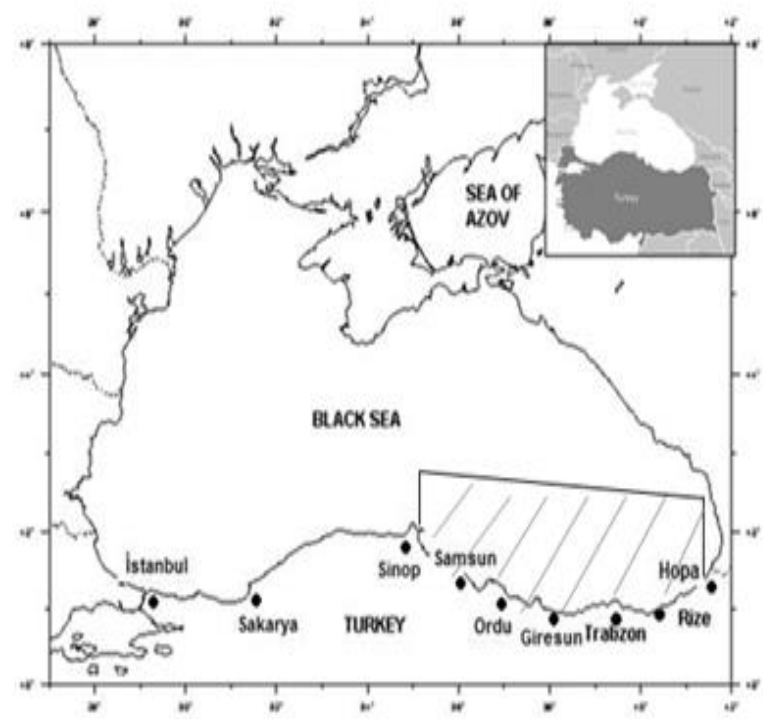

Figure 1. Sampling stations
Totally 439 specimens collected, 155 were individuals of $U$. scaber, 112 were indv. of $G$. niger and 172 were indv. of $N$. melanostomus. The samples were caught by bottom trawl nets with $40 \mathrm{~mm}$ mesh size in the cod end, purse seine nets with 12 $-15 \mathrm{~mm}$ mesh size in the bunt and gillnets with $34-36 \mathrm{~mm}$ mesh size).

Total length and weight of the samples were measured and weighed to within $1 \mathrm{~mm}$ and $0.01 \mathrm{~g}$ precision, respectively. The sagittal otoliths were removed from each fish, cleaned in alcohol, dried and fixed on ELISA microplate. Age was estimated by stereomicroscope (Leica MZ75); was performed by different researcher. The left or right otolith was used for age estimation depending on the clarification of the annulus.

The length-weight relationship was estimated with the formulae of $\mathrm{W}=\mathrm{aL}$ for both sexes, where $\mathrm{a}$ and $\mathrm{b}$ are constant, $W$ is the total weight $(\mathrm{g})$, and $\mathrm{L}$ is the total length $(\mathrm{cm})$ (Ricker, 1975). The von Bertalanffy growth parameters were calculated for each sex group by using the formulae of $L t=L_{\infty}\left(1-e^{-k(t-}\right.$ $\left.t_{0}\right)$ ), where $L_{\infty}$ is asymptotic length $(\mathrm{cm}), t$ is age (year), $k$ is the growth rate (year -1$)$, and $t_{0}$ is the hypothetical age at zero length (year) (Beverton and Holt, 1957; Pauly, 1983; Sparre and Venema, 1992; King, 1995). The instantaneous total mortality coefficient $(Z)$ was calculated by the formulae of $Z=$ InS (Ricker, 1975), where $S$ is the survival rate. Natural mortality rate $(\mathrm{M})$ was determined by $\mathrm{M}=0.8 \times \exp (-0.0152$ $0.279 \operatorname{Ln} L \infty+0.6543 \operatorname{Ln} K+0.463 \operatorname{LnT}$ ), where $T$ is the average annual water temperature in the fishing area $\left({ }^{\circ} \mathrm{C}\right)$ (Ricker, 1975; King, 1995). Fishing mortality (F) was estimated from $\mathrm{F}=\mathrm{M}-\mathrm{Z}$ (Gulland, 1971). All statistics (student $\mathrm{t}$ test) and graphs were carried out Microsoft Excel software ${ }^{\circledR}$.

\section{RESULTS}

In this study, 155 U. scaber specimens were found in between 5.2 and $23.4 \mathrm{~cm}$. Samples were mainly distributed in the range of $10.0-14.0 \mathrm{~cm}(57 \%)$. Mean length of $U$. scaber was calculated as $14.87 \pm 3.436 \mathrm{~cm}$ for females, $14.45 \pm 3.488 \mathrm{~cm}$ for males and $12.44 \pm 4.659 \mathrm{~cm}$ for overall samples. Mean weight was estimated as $66.68 \pm 25.920 \mathrm{~g}$ for females, $59.80 \pm 23.521 \mathrm{~g}$ for males and $47.59 \pm 24.370 \mathrm{~g}$ for all specimen. No significant differences were identified between the lengths of this species for males and females $(P>0.05)$. Majority of samples were represented by females as $58 \%$. Figure 2 shows the lengthweight relationships for females, males and both sexes. The age of $U$. scaber was estimated in the range of $0-V$. The maximum age group was determined as $V$ years for both sexes (Table 1).

The age-length and age-weight relationships were given in Figure 3. The Von Bertalanffy growth equation (VBGE) of the $U$. scaber was determined for sexes, females and males as $L_{t}=32.68\left(1-e^{-0.16(t+1.71)}\right), \quad L t=38.82\left(1-e^{-0.12(t+2.00)}\right), \quad L t=31.07\left(1-e^{-}\right.$ $0.15(t+1.75))$, respectively (Table 2$)$. The instantaneous total mortality rate $(Z)$ of $U$. scaber was calculated as 0.40 year $^{-1}$, natural mortality $(\mathrm{M})$ as 0.33 year- $^{-1}$ and fishing mortality $(\mathrm{F})$ as 0.07 year-1 $^{-1}$ (Table 2). 
Table 1. Age, mean length and weight of species (I: Immature, F: Female, M: Male)

\begin{tabular}{|c|c|c|c|c|c|c|c|c|c|c|}
\hline \multicolumn{5}{|c|}{ Uranoscopus scaber } & \multicolumn{3}{|c|}{ Gobius niger } & \multicolumn{3}{|c|}{ Neogobius melanostomus } \\
\hline Age & Sex & $\mathrm{N}$ & $\mathrm{L}(\mathrm{cm}) \pm \mathrm{SD}$ & $W(g) \pm S D$ & $\mathrm{~N}$ & $\mathrm{~L}(\mathrm{~cm}) \pm \mathrm{SD}$ & $W(g) \pm S D$ & $\mathrm{~N}$ & $\mathrm{~L}(\mathrm{~cm}) \pm \mathrm{SD}$ & $W(g) \pm S D$ \\
\hline \multirow{4}{*}{0} & I & 10 & $6.72 \pm 0.839$ & $6.19 \pm 2.096$ & & & & & & \\
\hline & $\mathbf{F}$ & 10 & $7.52 \pm 0.404$ & $19.06 \pm 2.141$ & 4 & $7.20 \pm 0.381$ & $6.76 \pm 1.274$ & 9 & $7.49 \pm 0.611$ & $7.01 \pm 2.024$ \\
\hline & $M$ & 8 & $7.33 \pm 0.458$ & $18.22 \pm 3.182$ & 1 & $6.80 \pm 0.704$ & $4.09 \pm 1.822$ & 9 & $6.69 \pm 0.377$ & $5.00 \pm 1.512$ \\
\hline & $\mathrm{I}+\mathrm{F}+\mathrm{M}$ & 28 & $7.13 \pm 1.376$ & $7.68 \pm 4.602$ & 5 & $7.12 \pm 0.511$ & $6.22 \pm 1.467$ & 18 & $7.11 \pm 0.544$ & $6.74 \pm 1.935$ \\
\hline \multirow{3}{*}{1} & $\mathbf{F}$ & 44 & $11.86 \pm 0.655$ & $27.15 \pm 7.392$ & 41 & $9.83 \pm .0836$ & $13.68 \pm 4.633$ & 60 & $12.88 \pm 0.810$ & $26.44 \pm 3.714$ \\
\hline & $M$ & 15 & $11.72 \pm 0.897$ & $25.59 \pm 7.072$ & 29 & $9.88 \pm 0.816$ & $13.49 \pm 4.227$ & 22 & $12.20 \pm 0.837$ & $24.61 \pm 3.127$ \\
\hline & $\mathrm{F}+\mathrm{M}$ & 59 & $11.80 \pm 0.667$ & $26.52 \pm 7.206$ & 70 & $9.85 \pm 0.822$ & $13.74 \pm 4.421$ & 82 & $12.54 \pm 0.834$ & $25.43 \pm 3.534$ \\
\hline & $F$ & 16 & $13.97 \pm 0.451$ & $47.78 \pm 5.337$ & 9 & $11.98 \pm 0.365$ & $25.57 \pm 2.811$ & 25 & $14.36 \pm 0.497$ & $42.01 \pm 3.868$ \\
\hline \multirow[t]{3}{*}{2} & M & 8 & $13.88 \pm 0.544$ & $45.35 \pm 9.741$ & 5 & $11.80 \pm 0.318$ & $22.41 \pm 2.768$ & 16 & $14.12 \pm 0.471$ & $36.52 \pm 3.070$ \\
\hline & $F+M$ & 24 & $13.94 \pm 0.474$ & $46.97 \pm 6.988$ & 14 & $11.92 \pm 0.357$ & $24.59 \pm 2.994$ & 41 & $14.20 \pm 0.481$ & $38.32 \pm 3.446$ \\
\hline & $F$ & 10 & $15.82 \pm 0.679$ & $73.78 \pm 9.696$ & 8 & $13.02 \pm 0.298$ & $29.63 \pm 4.371$ & 9 & $16.66 \pm 0.935$ & $60.21 \pm 7.611$ \\
\hline \multirow[t]{3}{*}{3} & M & 9 & $15.70 \pm 0.508$ & $67.85 \pm 8.245$ & 5 & $12.90 \pm 0.285$ & $29.88 \pm 4.033$ & 8 & $16.05 \pm 1.094$ & $52.68 \pm 7.041$ \\
\hline & $\mathrm{F}+\mathrm{M}$ & 19 & $15.76 \pm 0.591$ & $70.97 \pm 8.279$ & 13 & $12.97 \pm 0.274$ & $29.73 \pm 4.071$ & 17 & $16.32 \pm 0.995$ & $56.21 \pm 7.215$ \\
\hline & $\mathbf{F}$ & 9 & $18.05 \pm 0.837$ & $110.89 \pm 10.598$ & 4 & $14.77 \pm 0.741$ & $42.69 \pm 7.074$ & 3 & $17.85 \pm 0.703$ & $60.83 \pm 7.804$ \\
\hline \multirow[t]{3}{*}{4} & $M$ & 6 & $18.25 \pm 1.061$ & $101.84 \pm 9.041$ & 3 & $14.37 \pm 0.785$ & $42.24 \pm 4.447$ & 2 & $17.55 \pm 0.711$ & $55.86 \pm 7.052$ \\
\hline & $\mathrm{F}+\mathrm{M}$ & 15 & $18.09 \pm 0.822$ & $109.08 \pm 9.512$ & 7 & $14.57 \pm 0.744$ & $42.47 \pm 5.894$ & 5 & $17.70 \pm 0.703$ & $59.29 \pm 6.814$ \\
\hline & $F$ & 8 & $21.44 \pm 1.439$ & $165.57 \pm 12.741$ & 2 & $15.60 \pm 2.010$ & $50.08 \pm 2.757$ & 3 & $19.67 \pm 1.252$ & $111.61 \pm 8.984$ \\
\hline \multirow[t]{3}{*}{5} & $M$ & 2 & $21.01 \pm 0.882$ & $159.34 \pm 14.375$ & 1 & 15.50 & 47.22 & 1 & 18.00 & 98.46 \\
\hline & $F+M$ & 10 & $21.33 \pm 1.217$ & $163.08 \pm 13.194$ & 3 & $15.57 \pm 1.971$ & $49.61 \pm 2.841$ & 4 & $19.25 \pm 1.258$ & $108.32 \pm 9.014$ \\
\hline & $F$ & & & & & & & 2 & $24.50 \pm 1.110$ & $177.53 \pm 9.083$ \\
\hline \multirow[t]{3}{*}{6} & M & & & & & & & 1 & 23.80 & 160.59 \\
\hline & $\mathrm{F}+\mathrm{M}$ & & & & & & & 3 & $24.15 \pm 1.121$ & $169.06 \pm 9.175$ \\
\hline & $F$ & & & & & & & 1 & 26.40 & 269.88 \\
\hline \multirow{3}{*}{7} & $M$ & & & & & & & 1 & 25.60 & 249.66 \\
\hline & $\mathrm{F}+\mathrm{M}$ & & & & & & & 2 & $\begin{array}{l}26.00 \pm \\
0.565\end{array}$ & $259.77 \pm 14.298$ \\
\hline & $F$ & 90 & $14.87 \pm 3.436$ & $66.68 \pm 25.920$ & 68 & $10.86 \pm 2.070$ & $19.47 \pm 11.094$ & 112 & $\begin{array}{l}13.48 \pm \\
3.548\end{array}$ & $30.38 \pm 11.742$ \\
\hline \multirow{4}{*}{ Total } & M & 43 & $14.45 \pm 3.488$ & $59.80 \pm 23.521$ & 44 & $10.77 \pm 2.006$ & $19.06 \pm 11.235$ & 60 & $12.66 \pm$ & $29.32 \pm 15.716$ \\
\hline & & & & & & & & & 3.746 & \\
\hline & $\mathrm{F}+\mathrm{M}$ & & & & 112 & $10.80 \pm 2.036$ & $19.31 \pm 11.100$ & 172 & $\begin{array}{l}12.86 \pm \\
3.613\end{array}$ & $28.96 \pm 14.607$ \\
\hline & $\mathrm{I}+\mathrm{F}+\mathrm{M}$ & 155 & $12.44 \pm 4.659$ & $47.59 \pm 24.370$ & & & & & & \\
\hline
\end{tabular}

Table 2. Von Bertalanffy growth parameters, mortality and survival rates of species

\begin{tabular}{llllllll}
\hline Species & $\mathbf{L}_{\infty}$ & $\mathbf{k}$ & $\mathbf{t}_{0}$ & $\mathbf{S}$ & $\mathbf{Z}$ & $\mathbf{F}$ & $\mathbf{M}$ \\
\hline Uranoscopus scaber & 32.68 & 0.16 & -1.71 & 0.67 & 0.40 & 0.07 & 0.33 \\
Gobius niger & 17.95 & 0.27 & -1.50 & 0.51 & 0.68 & 0.14 & 0.54 \\
Neogobius melanostomus & 36.08 & 0.14 & -1.57 & 0.58 & 0.54 & 0.25 & 0.29 \\
\hline
\end{tabular}

In total, 112 sample units were caught for G. niger distributing between 6.80 and $15.8 \mathrm{~cm}$. The majority of specimens were varied in 9.0-11.9 cm (56\%). Females were found dominant in this distribution (61\%). Mean length and mean weight were estimated for each sex and pooled samples of both sexes. Mean length of $G$. niger was found females, males and both sexes as $10.86 \pm 2.070 \mathrm{~cm}, 10.77 \pm 2.006 \mathrm{~cm}$ and $10.80 \pm 2.036 \mathrm{~cm}$, respectively. Mean weight was also determined for females, males and pooled samples of both sexes as $19.47 \pm 11.094 \mathrm{~g}, 19.06 \pm 11.235 \mathrm{~g}$ and $19.31 \pm 11.100$ $\mathrm{g}$, respectively. Differences between the lengths of this species for males and females were not found statistically significant $(P>0.05)$. Length-weight relationships of $G$. niger were estimated as $W=0.0180 L^{2.856}$ for both sexes, $W=0.0152 L^{2.964}$ for females and $W=0.0107 L^{3.098}$ for males (Figure 2). The age composition of the species was observed between $0-\mathrm{V}$ years. The most dominant age group was determined as I age class (Table 1).

Figure 3 shows the age-length and age-weight relationship for this species. VBGE was computed for females, males and pooled samples as $\mathrm{Lt}=18.57\left(1-\mathrm{e}^{-0.26(t+1.78)}\right), \quad \mathrm{Lt}=17.81\left(1-\mathrm{e}^{-}\right.$ $0.30(t+1.57)$ ) and $L t=17.95\left(1-e^{-0.27(t+1.50)}\right)$, respectively (Table 2). The instantaneous total mortality rate $(Z)$ of $G$. niger was calculated 0.68 year $^{-1}$, natural mortality $(\mathrm{M})$ as 0.54 year $^{-1}$ and fishing mortality $(F)$ as 0.14 year-1 $^{-1}$ (Table 2 ). 

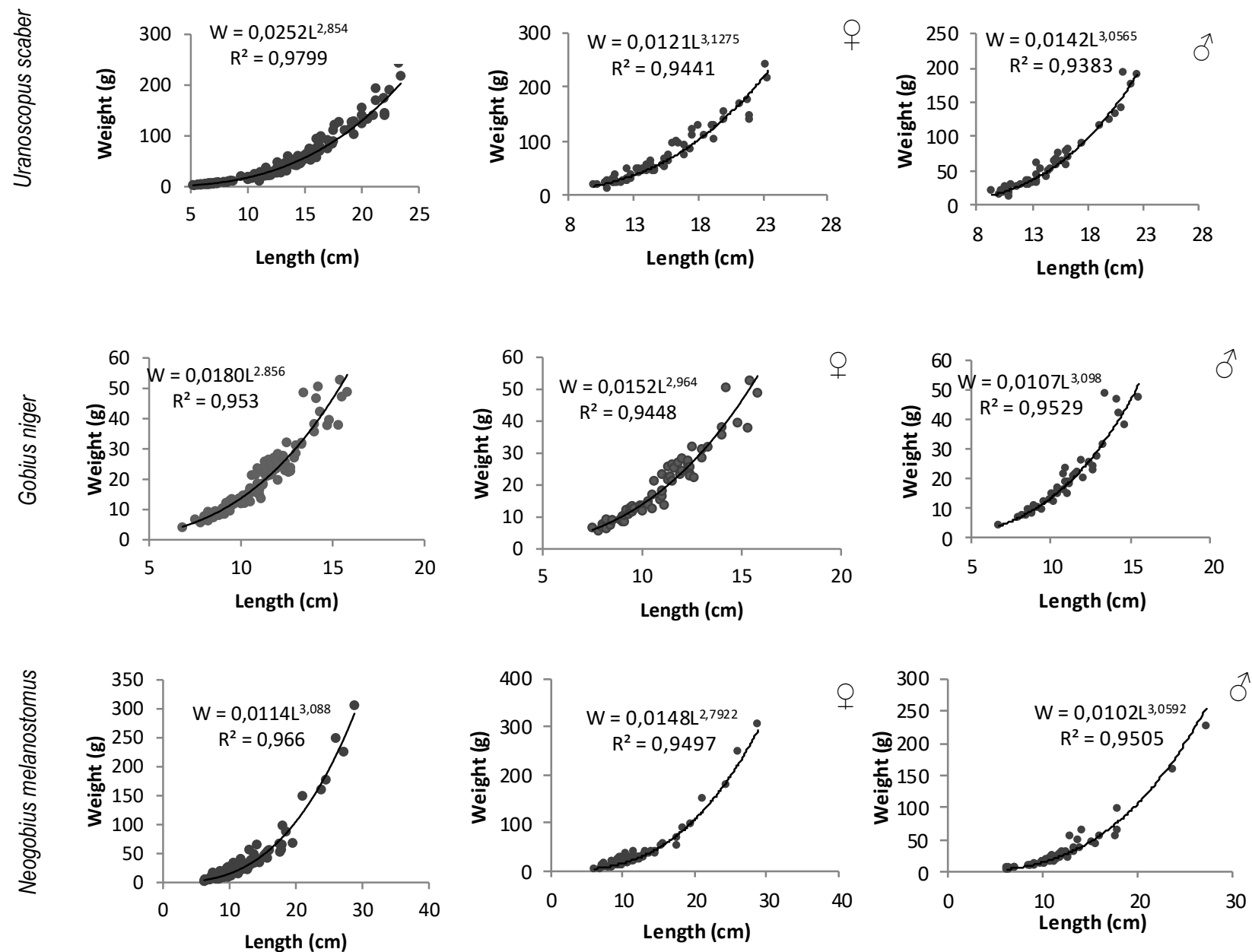

Figure 2. Length-weight relationships of species

In total, $172 \mathrm{~N}$. melanostomus samples were examined in this research. The sample lengths were found $\min .6 .5 \mathrm{~cm}$ and max. $26.40 \mathrm{~cm}$. The majority (69\%) of them ranged from 8.0 $13.0 \mathrm{~cm}$. The mean length of this species was estimated as $12.86 \pm 3.613 \mathrm{~cm}$ for sexes, $13.48 \pm 3.548 \mathrm{~cm}$ for females and $12.66 \pm 3.746 \mathrm{~cm}$ for males. The mean weight of $N$. melanostomus was calculated as $28.96 \pm 14.607 \mathrm{~g}$ for pooled samples of both sexes, $30.38 \pm 11.742 \mathrm{~g}$ for females and $29.32 \pm 15.716 \mathrm{~g}$ for males. Differences between the lengths of this species for males and females were found statistically insignificant $(P>0.05)$. The length-weight relationships of this species were determined as $W=0.0114 L^{3.088}$ for both sexes, $W=0.0148 L^{2.79}$ for females and $W=0.0102 L^{3.06}$ for males (Figure 2). The age composition of $N$. melanostomus varied in $0-\mathrm{VII}$ years old for males and females (Table 1). The most dominant age class was I age class (48\%), followed by II age class (37\%). VBGE of this species was calculated for both sexes as $L t=36.08\left(1-e^{-0.14(t+1.57))}\right)$, for females as $L t=38.08\left(1-e^{-0.12(t+1.62)}\right)$ and for males as $L t=33.87\left(1-\mathrm{e}^{-0.16(t+1.33)}\right)$ (Table 2). The instantaneous total mortality rate (Z) of $N$. melanostomus was calculated as 0.54 year-1, natural mortality $(M)$ as 0.29 year $^{-1}$ and fishing mortality $(F)$ as 0.25 year- $^{-1}$ (Table 2). 


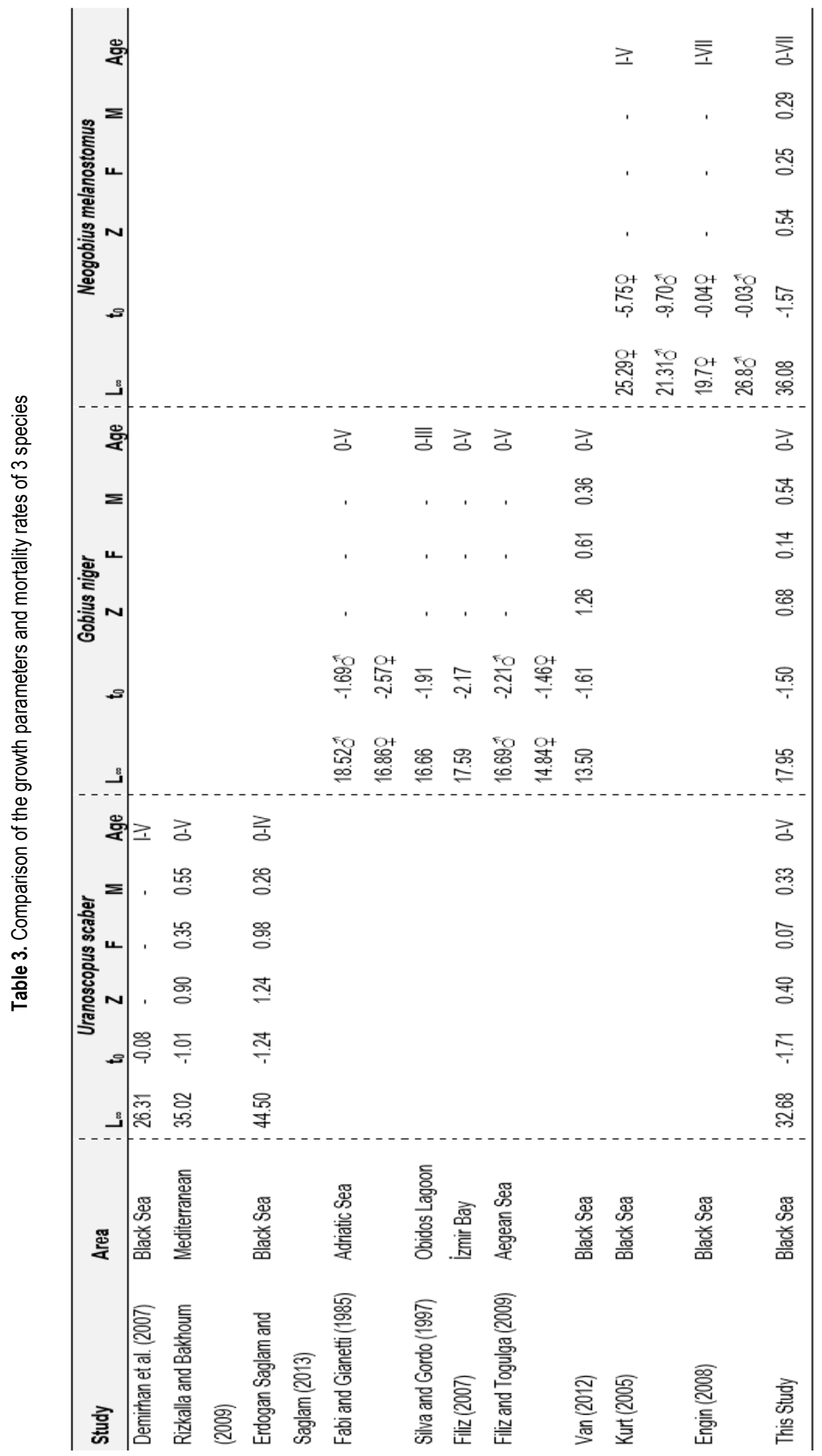



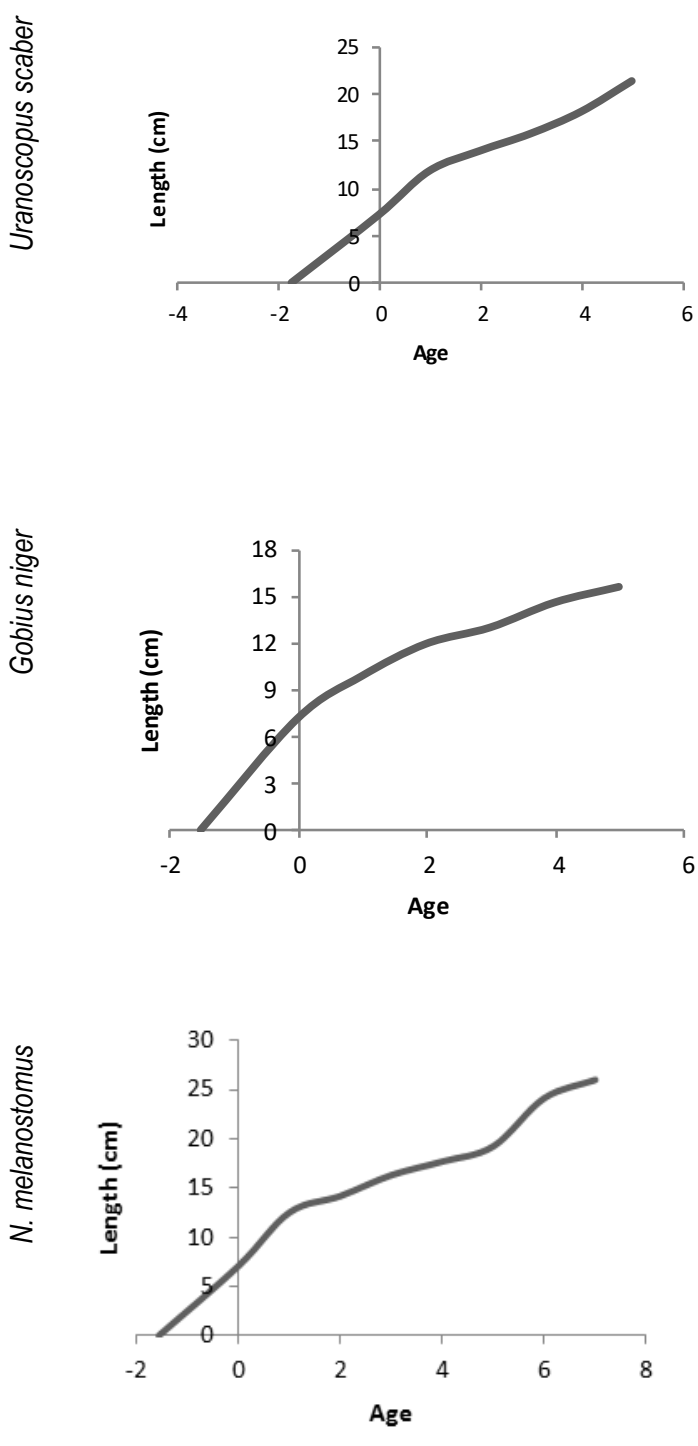

Figure 3. Age-length and age-weight relationships of species

\section{DISCUSSION}

The growth parameters and mortality rates of the $U$. scaber supported by results of Rizkalla and Bakhoum (2009). The growth and mortality parameters in this study are generally found different from the past studies carried out for the Black Sea (Erdoğan Sağlam and Sağlam, 2013; Demirhan et al., 2007). The reason for the differences between them may be explained by using the Bhattacharya method in the age determination by Erdoğan Sağlam and Sağlam (2013) and reading of false annulus in the age determination by Demirhan et al. (2007).

The results of this study for growth parameters of $G$. niger supported the findings of Fabi and Gianetti (1985). However,
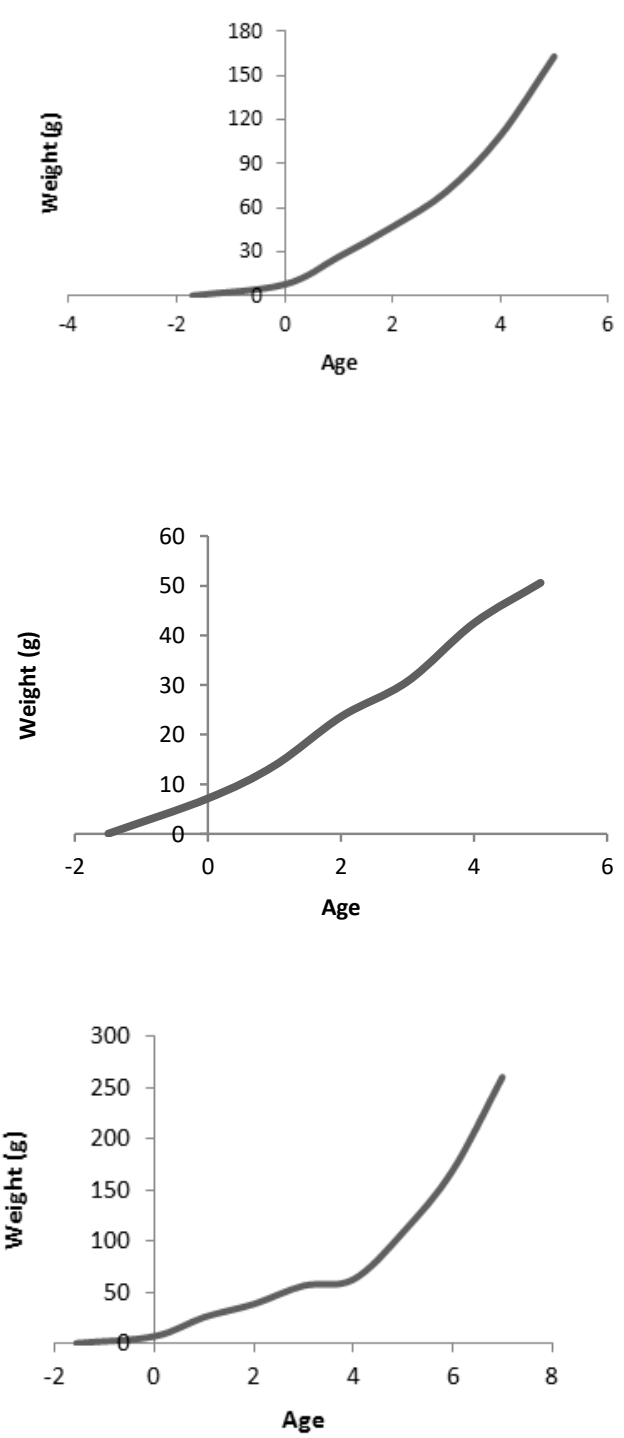

there were lower values were reported by Silva and Gordo (1997), Filiz (2007), Filiz and Toğulga (2009) and Van (2012) for this species. The differences can be understood by the different sampling period and gear. Age determination results of this study was found similar to Filiz (2007), Filiz and Toğulga (2009) and Van (2012), however, the results showed different from the findings of Fabi and Gianetti (1985). Mortality rates were only found similar to Van (2012). The values of growth parameters for $N$. melanostomus are higher than the values observed by Kurt (2005) and Engin (2008). Age analysis of this study was estimated using by otoliths. The differences can be caused due to reading of false rings in otoliths by past studies. This study represents the mortality rates of the relating species for the first time (Table 3). 


\section{CONCLUSION}

The values of this study might be accepted as a baseline for researchers on these species in the future. These species have not commercial values and are called discard in fishing operations. There are no management measures (i.e MLS fishing seasons or gear limitations) on these species in Turkey. Authorities should take these measures to regulate for non-

\section{REFERENCES}

Baron, V.D. (2009). Electric Discharges of Two Species of Stargazers from the South China Sea (Uranoscopidae, Perciformes) Journal of Ichthyology 49 : 11, 1065-1072.

Bennett, M.V.L. (1971). Electric Organs. In: W.S. Hoar \& D.J. Randall (EDS) Fish physiology. Academic Press, New York, pp. 347-491.

Beverton, R.J. \& Holt, S.J. (1957). On the dynamics of exploited fish populations. Fisheries investment series 2. Vol. 19" U.K. Ministry of Agriculture and Fisheries, London.

Corkum, L.D., Sapota, M.R. \& Skora, K.E. (2004). The Round goby, Neogobius melanostomus, a fish invader on both sides of the Atlantic Ocean. Biological Invasions 6: 173-181.

Demirhan, S.A., Can, M. F. \& Seyhan, K. (2007). Age and growth of stargazer (Uranoscopus scaber L., 1758) in the southeastern Black Sea. Journal of Applied Ichthyology 23: 692-694.

Engin, S. (2008). Bio-ecological characteristic of some gobies Neogobius platyrostris (Pallas, 1814), Neogobius melanostomus (Pallas, 1814), Gobius paganellus Linnaeus, 1758 and Gobius cobitis Pallas, 1814 in the south eastern Black Sea rocky shore coastal ecosystem. PhD Thesis, Trabzon, Turkey: Karadeniz Technical University, (in Turkish), 198 pp.

Erdogan Saglam, N., Saglam, C. (2013). Population parameters of Stargazer (Uranoscopus scaber Linnaeus, 1758) in the southeastern Black Sea region during the 2011-2012 fishing season. Journal of Applied Ichthyology. 29: 1313-1317. doi: 10.1111/jai.12305

Fabi, G. \& Giannetti, G. (1985). Growth parameters of the black goby (Gobius niger L.) in The Adriatic Sea, based on otoliths reading. Rapp. Comm. int. Mer Medit. 29, 8

Filiz, H. (2007). The biological characteristics of black goby (Gobius niger L. 1758) in Izmir and Candarli Bays. PhD Thesis, Ege University, İzmir, Turkey. 157 pp (in Turkish)

Filiz, H. \& Toğulga, M. (2009). Age and growth, reproduction and diet of the black goby, (Gobius niger) from Aegean Sea, Turkey. Journal of FisheriesSciences.com, 3 (3): 243-265. doi: 10.3153/jfscom.2009030

Froese, R. \& Pauly, D. (2009). FishBase. World Wide Web electronic publication. http://www.fishbase.org, version (09/2009).

Gulland, J.A. (1971). Science and fishery management. J. Cons. CIEM., 33(3), 471-477. doi: 10.1093/icesjms/33.3.471

Gümüş, A. \& Kurt, A. (2009). Age structure and growth by otolith interpretation of Neogobius melanostomus (Gobiidae) from Southern Black Sea. Cybium, 33(1): 29-37.

Hureau, J.C. (1986). Mullidae. In: P.J.P. Whitehead, M.L. Bauchot, J.C Hureau, J. Nielsen \& E. Tortonese (eds) Fishes of the North-eastern Atlantic and the Mediterranean. UNESCO, Paris, France.

Katalay, S. \& Parlak, H. (2002). The Effects of water pollution on blood parameters of black goby (Gobius niger Linn, 1758). E.U. Journal of Fisheries \& Aquatic Sciences. 19 (1-2): $115-121$

King, M. (1995). Fisheries Biology. Assessment and Management. Osney Mead. Oxford, England.

Kurt, A. (2005). The determination of ageing methods and growth parameters of round goby, Neogobius melanostomus (Pallas, 1814) (Gobiidae) inhabiting the Black Sea. MSc Thesis. Ondokuz Mayıs University, Samsun, Turkey (in Turkish). commercial fish species in order to provide sustainable fisheries and protect the environment in Turkey.

\section{ACKNOWLEDGEMENTS}

This article has been prepared using data obtained by a project supported by the Karadeniz Technical University Scientific Research Fund (2008.117.001.1).

Lodge, D.M. (1993). Species invasions and deletions: Community effects and responses to climate and habitat change. In: P.M. Kareiva, J.G. Kingsolver \& R.B. Hurey (eds) Biotic interactions and global change. Sinauer Associates, Sunderland, MA. pp. 367-387.

Macinnis, A.J. \& Corkum, L.D. (2000). Age and growth of round goby Neogobius melanostomus in the upper Detroit River. Transactions of the American Fisheries Society. 12: 852-858.

Miller, P.J. (1986). Gobiidae. In: Whitehead P.J.P., Bauchot M.L., Hureau J. C., Nielsen J. \& Tortonese E. Fishes of the North-Eastern Atlantic and the Mediterranean, Vol. 3, UNESCO, Paris

Moller, P. (1995). Electric Fishes. History and Behavior. London, Chapman \& Hall.

Nelson, J.S. (1994). Fishes of the World. New York: John Wiley. ISBN-13: 978 $0-471-25031-9$

Pauly, D. (1983). Some simple methods for the assessment of tropical fish stocks. FAO Fish. Tech. Pap. No: 234. Rome.

Pickens, P.E. \& Mcfarland, W.N. (1964). Electric discharge and associated behavior in the stargazer. Animal Behavior 12: 326-367.

Ricker, W.E. (1975). Computation and interpretation of biological statistics of fish populations. Bull. 191. Fish. Res. Board. Canada

Rizkalla, S.I. \& Bakhoum, S.A. (2009). Some biological aspects of Atlantic stargazer Uranoscopus scaber Linnaeus, 1758 (Family: Uranoscopidae) in The Egyptian Mediterranean water. Turkish Journal of Fisheries and Aquatic Sciences 9: 59-66.

Silva, M.N. \& Gordo, L.S. (1997). Age, growth and reproduction of the black goby Gobius niger from Obidos Lagoon, Portugal. Cahiers Biology de Marine, 38: 175-180.

Simonovic, P., Paunovic, M. \& Popovic, S. (2001). Morphology, feeding, and reproduction of the round goby, Neogobius melanostomus (Pallas), in the Danube River basin, Yugoslavia. J. Great Lakes Res. 27(3): 281-289.

Skora, K.E. \& Stolarski, J. (1993). New fish species in the Gulf of Gdansk Neogobius sp. Neogobius melanostomus (PALLAS, 1811). Notes Bull. Sea. Fish Inst 1: 83

Sokolowska, E. \& Fey, D.P. (2011). Age and growth of the round goby Neogobius melanostomus in the Gulf of Gdansk several years after invasion. Is the Baltic Sea a new promised land? Journal of Fish Biology, 78: 1993-2009.

Sparre, P. \& Venema, S.C. (1992). Introduction to tropical fish stock assessment, Part 1-Manual. FAO Fisheries Technical Paper 306-1 rev. 1.

Van, A. (2012). Determination of most reliable ageing method in black goby (Gobius niger L, 1758) and comparison of growth parameters obtained from two sampling localities. Ondokuz Mayıs University, MSc Thesis, Samsun, Turkey (in Turkish) 154 pp.

Yankova, M., Raykov, V., Ivanova, P., Diasamidze, R., Mgeladze, M., Radu, G., Nicolaev, S., Agapov, S., Grinchenko, M., Oral, M., Duzgunes, E., Ozturk, B., Bat, L., Karpova, E., Shlyakhov, V. \& Boltachev, A. (2011). Black Sea fishes list, IUCN Status. Bulgaria, Georgia, Romania, Russian Federation, Turkey, Ukraine. Istanbul: Black Sea Commission Publications 